\title{
ARRB2 wt Allele
}

National Cancer Institute

\section{Source}

National Cancer Institute. ARRB2 wt Allele. NCI Thesaurus. Code C129046.

Human ARRB2 wild-type allele is located in the vicinity of $17 \mathrm{p} 13$ and is approximately 11 $\mathrm{kb}$ in length. This allele, which encodes beta-arrestin- 2 protein, plays a role in the downregulation of $\mathrm{G}$ protein-coupled receptor signaling. 